\title{
How much effective are supplements in the treatment of osteoarthritis?
}

\author{
Takviyeler osteoartrit tedavisinde ne kadar etkilidir?
}

\author{
O. Şahap Atik, MD (1) \\ Professor of Orthopedic Surgery, Turkish Joint Diseases Foundation, Ankara, Turkey
}

Osteoarthritis (OA) is the most common form of arthritis and the leading cause of disability among middle-aged and elderly people. The pathogenesis and treatment of OA are very complex. ${ }^{[1,2]}$

Many people with OA use supplements in their diet for the treatment of OA. Glucosamine, chondroitin and methylsulfonylmethane (MSM) are the most wellknown. These supplements are available in pharmacies and health food stores without a prescription. Some patients and physicians accepted these supplements as a miracle treatment for OA. However, there are no published randomized controlled trials to confirm their long-term safety and effectiveness.

Lupis et al. ${ }^{[3]}$ conducted a study comparing glucosamine-chondroitin sulfate with or without MSM in grade I-II knee OA. They concluded that combination of glucosamine-chondroitin sulfateMSM showed clinical benefit for patients compared with glucosamine-chondroitin sulfate and placebo.

However, Ameye and $\mathrm{Chee}^{[4]}$ reported a systematic review of a range of nutraceuticals in OA including MSM and concluded that MSM showed "moderate" evidence of efficacy. Moreover, Brien et al. ${ }^{[5]}$ concluded in a meta-analysis that MSM is not clinically effective in the reduction of pain in the treatment of OA, and no definitive conclusions can currently be drawn from the data due to the mixed findings and the use of inadequate dosing periods. They recommended further investigation addressing methodological concerns including optimal dosage and treatment duration.

Recently, Liu et al. ${ }^{[6]}$ conducted a systematic review and meta-analysis on dietary supplements for treating OA. They showed that supplements provided moderate and clinically meaningful treatment effects on pain and function in patients with hand, hip or knee OA at short-term, although the quality of evidence was very low. Widely-used supplements such as glucosamine and chondroitin were either ineffective or showed small and clinically unimportant treatment effects.

In conclusion, there is no strong evidence to know how much effective these supplements are in the treatment of OA.

\section{REFERENCES}

1. Atik OŞ, Erdoğan D, Seymen CM, Bozkurt HH, Kaplanoğlu GT. Is there crosstalk between subchondral bone, cartilage, and meniscus in the pathogenesis of osteoarthritis? Eklem Hastalik Cerrahisi 2016;27:62-7.

2. Sezgin EA, Atik OŞ. Are orthobiologics the next chapter in clinical orthopedics? A literature review. Eklem Hastalik Cerrahisi 2018;29:110-6.

3. Lubis AMT, Siagian C, Wonggokusuma E, Marsetyo AF, Setyohadi B. Comparison of Glucosamine-Chondroitin Sulfate with and without Methylsulfonylmethane in Grade I-II Knee Osteoarthritis: A Double Blind Randomized Controlled Trial. Acta Med Indones 2017;49:105-111.

4. Ameye LG, Chee WS. Osteoarthritis and nutrition. From nutraceuticals to functional foods: a systematic review of the scientific evidence. Arthritis Res Ther 2006;8:R127.

5. Brien S, Prescott P, Lewith G. Meta-analysis of the related nutritional supplements dimethyl sulfoxide and methylsulfonylmethane in the treatment of osteoarthritis of the knee. Evid Based Complement Alternat Med 2011;2011:528403.

6. Liu X, Machado GC, Eyles JP, Ravi V, Hunter DJ. Dietary supplements for treating osteoarthritis: a systematic review and meta-analysis. Br J Sports Med 2018;52:167-175. 